\title{
An overview of the mitigating mechanisms of the fitness cost of mutations associated with pesticide resistance in arthropods
}

\author{
Ana Cristina Silva de Lima \\ Daniela Cristina De Toni \\ Norma Machado da Silva * \\ Federal University of Santa Catarina \\ Departament of Cell Biology, Embriology and Genetics, Center for Biological Sciences \\ Campus Universitário Reitor João David Ferreira Lima, Trindade \\ CEP 88.040-900, Florianópolis - SC, Brasil \\ * Corresponding author \\ norma.machado@ufsc.br
}

Submetido em 01/07/2020

Aceito para publicação em 25/09/2020

\section{Resumo}

Uma visão geral dos mecanismos atenuadores do custo de aptidão de mutações associadas à resistência a pesticidas em artrópodes. Alelos que causam resistência a pesticidas também podem trazer algum custo fisiológico para seus portadores, uma vez que afetam outras características como a reprodução e a sobrevivência. Entretanto, trabalhos têm descrito que em alguns artrópodes mecanismos atenuadores do custo fisiológico também têm sido selecionados. Esta revisão traz um levantamento dos mecanismos atenuadores do fitness descritos na literatura e que podem contribuir na manutenção da resistência em artrópodes. Consultas foram realizadas junto aos bancos de dados Pubmed e Scopus, durante o período de outubro de 2019 a janeiro de 2020 para busca de referências relacionadas ao tema, utilizando combinações de palavras-chave, o operador Booleano AND e usando critérios de inclusão e exclusão. Foram selecionados 61 artigos científicos, a partir do título e resumo. Foram encontrados diferentes mecanismos de atenuação que foram classificados em nove categorias de acordo com sua forma de ação descrita no artigo. Diptera foi a ordem mais abordada (24 artigos), representada principalmente por mosquitos da família Culicidae (17 artigos). A duplicação gênica, principalmente de genes da acetilcolinesterase, foi o mecanismo mais encontrado (14 artigos), e o que apresentou maior variedade de espécies em que ocorre (oito espécies de três Ordens, incluindo insetos e aracnídeos).

Palavras-chave: Atenuação; Genótipo de resistência; Inseticidas químicos

\section{Abstract}

Alleles that cause resistance to pesticides may also result in host physiological cost, as they can impair phenotypes such as reproduction and survival. However, works have described that in some arthropods mechanisms that mitigate the physiological cost have also been selected. This review covers a survey of the fitness attenuating mechanisms reported in the literature that can contribute to the maintenance of resistance in arthropods. Searches were made in the Pubmed and Scopus databases, from October 2019 to January 2020, to find references related to the topic, using combinations of key words, the Boolean operator AND, as well as inclusion and exclusion criteria. Sixty-one scientific articles were obtained, which were selected from the title 
and abstract. Different attenuation mechanisms were found and were classified into nine categories according to the mechanism of action described in the article. The Diptera Order was the most addressed in the articles (24 articles), represented mainly by the Culicidae family mosquitoes (17 articles). Gene duplication, mainly of acetylcholinesterase genes, was the mechanism most found (14 articles), and the one with the greatest variety of species in which it occurs (eight species from three Orders, including insects and arachnids).

Key words: Chemical insecticides; Mitigation; Resistance genotype

\section{Introduction}

Pesticide resistance is defined as an inheritable change in the sensitivity of a population of pests to a particular compound, which is perceived by the repeated failure of a particular target-vector to reach the expected level of control when the product is used according to the recommendations of control policies (IRAC, 2014). Usually, the emergence of resistance is related to the continuous and indiscriminate use of chemical compounds, such as insecticides, leading to a selective pressure on a vector population, resulting in the survival of only a few phenotypically resistant individuals, which will have the opportunity to pass this phenotype on to the offspring. This will contribute to the increase in the frequency of the genetic variant that confers resistance in overall field population (HEMINGWAY; RANSON, 2000). There are currently over 600 species of arthropods that are resistant to different types of pesticides (ARTHROPOD PESTICIDE RESISTANCE DATABASE, 2020).

Alterations in insecticide sensitivity can be caused by different mechanisms, such as: insensitivity at the target site of the insecticide action (change in the target protein); increase in detoxification or excretion (metabolic mechanisms), reduction in insecticide ability to penetrate and behavioral resistance (HEMINGWAY, 2000). Some mutations in genes that encode proteins that are the target for insecticide action can render them insensitive to these compounds. Most insecticides are neurotoxic, targeting proteins such as acetylcholinesterase, sodium channels and the GABA receptor, so mutations in the genes encoding such proteins can compromise the effectiveness of insecticides. Metabolic resistance involves an increase either in the sequestration or metabolism of the insecticide through the enzyme action from different families, the main ones being glutathione-S-transferases or GSTs (efficient in the action against pyrethroids, organophosphates and organochlorines), esterases or ESTs (effective in action against organophosphates and carbamates) and cytochrome P450 or CYPs (effective in action against most types of chemical insecticides). Metabolic resistance can be caused by the overexpression of one or more enzymes, changes in the catalytic properties of the enzyme, or both (HEMINGWAY, 2000; HEMINGWAY et al., 2004).

Changes in the composition of the exoskeleton that increase the thickness by adding proteins and lipids generate a reduction in cuticular penetration by the insecticide. The reduction in the insecticide's absorption rate, when compared to the metabolic mechanisms and changes in the target site of action of the insecticide, is considered of secondary importance, since it alone does not cause worrying levels of resistance. However, in combination with other mechanisms it can cause an increase in resistance, compromising control strategies (BRAGA; VALLE, 2007). Some insecticides such as permethrin (a type of pyrethroid) can have a repellent effect and cause behavioral changes, so that the insect becomes less exposed to this compound (MATHENGE et al., 2001).

The selection of a new characteristic can lead to the appearance of the pleiotropy phenomenon which, in a context of resistance, has been related to a gene mutation that can also influence the alteration of other characteristics in addition to providing resistance to insecticides. Studies have shown that some mutations that confer resistance can cause some cost in the fitness of their carriers since they can also alter other characteristics of the organism's life history. These changes are more easily observed in the absence of the selection pressure exerted by the insecticide (COUSTAU et al., 2000). 
Mutations conferring high levels of insecticide resistance have been associated with deleterious changes in some characteristics, such as less successful mating, lower fertility and hatchability; reduction of individuals who survive to adulthood; higher susceptibility to natural enemies or higher mortality overwintering, among others (BOIVIN et al., 2001; BERTICAT et al., 2008; KLIOT; GHANIM, 2012). There are several physiological costs that have been associated with resistance, and the intensity of that cost is directly related to the molecular basis of resistance. However, over time, attenuating fitness mechanisms have also been selected in some species of arthropods (FFRENCH-CONSTANT; BASS, 2017), although for most of them the molecular ways of acting to mitigate fitness costs have not yet been elucidated.

The review presented here sought to provide an overview of what has been described in the literature regarding the mechanisms that mitigate the fitness costs and that can contribute to maintaining resistance in different species of arthropods, and in which species this issue has been most investigated.

\section{Material and Methods}

\section{Data collect}

The search for articles was carried out in the PubMed (NCBI) and Scopus (Elsevier) databases from October 2019 to January 2020. The searches were performed using descriptors associated with the theme of this work. Therefore, 22 combinations of key words (Table 1) and the Boolean operator "AND" were used.

For the term trade-off, different numbers of articles were found in initial searches using the term with or without a hyphen, so both forms were used to ensure broader searches. The searches in the databases were carried out by two researchers independently that read the titles and abstracts of the articles that appeared in the searches with the key words (Table 1), first, to check if they could contain information that would answer the guiding questions of this work; and, second, if they were in agreement with the inclusion criteria. After this selection, the two researchers responsible for these searches made a consensus list of articles for reading. While reading these articles different information was noted as follows: Authors and Year; Title of Article; Species analyzed (Scientific name; Order; Family); Resistance mechanism; Fitness cost observed; Mitigation mechanism described.

TABLE 1: Combination of key words used to search for articles in the PubMed and Scopus databases.

\section{Key words}

Fitness cost and insecticide resistance

Fitness cost and pesticide resistance

Fitness cost and acaricides resistance

Fitness cost and pyrethroids

Fitness cost and organophosphates

Fitness cost and carbamates

Fitness cost and mosquitoes and insecticide resistance

Fitness cost and flies and insecticide resistance

Fitness cost and moths and insecticide resistance

Fitness cost and ticks and acaricide resistance

Fitness cost and insecticide resistance and arthropods

Fitness cost and insecticide resistance and insects

Fitness cost and pesticide resistance and arthropods

Fitness cost and pesticide resistance and insects

Amelioration and insecticide resistance

Amelioration and pesticide resistance

Trade-off and insecticide resistance

Tradeoff and insecticide resistance

Trade-off and pesticide resistance

Tradeoff and pesticide resistance

Trade-off and fitness cost and insecticide resistance

Tradeoff and fitness cost and insecticide resistance

\section{Inclusion and exclusion criteria}

Inclusion criteria used: studies in Portuguese and English, published until December 2019, that cited or described mechanisms involved in mitigating the fitness cost caused by resistance to some kind of chemical insecticide in arthropods.

Exclusion criteria used: studies addressing resistance to biological insecticides (Bacillus thuringiensis and Bacillus sphaericus toxins) and studies addressing plant resistance to herbicides. Review articles were also not included in the analysis. 


\section{Results}

After searching the two databases and drawing up a consensus list between the two researchers involved in this step, a total of 61 articles were selected for full reading. All selected articles were the results of the search using two or more key word combinations. Some articles (15) were considered "false positive" because, after reading, it was observed that they did not describe the mechanism for attenuating the fitness cost caused by insecticide resistance mutations (DURON et al., 2006; RIVERO et al., 2011; BRITO et al., 2013; 2019; RIBEIRO et al., 2014; WEETMAN et al., 2015; ZHANG et al., 2015; HSU et al., 2016; BAJDA et al., 2018; DAVID et al., 2018; SOMERS et al., 2018; VERNON et al., 2018; LIEBMAN et al., 2019; MA et al., 2019; YING et al., 2019). Some articles also did not describe which physical, physiological or behavioral characteristics were affected by the insecticide resistance mechanism or cited other articles where the strains or samples used were characterized. However, considering that the focus of this work is mitigation mechanisms, only those that did not describe such information were considered false positive.
Articles involving species of insects from different Orders and arachnid species (mites and ticks) were analyzed. The Order Diptera (Class Insecta) was the most frequent, with 24 articles found, represented mainly by mosquitoes of the Culicidae family (17 articles). For the Ixodida and Thrombidiformes Orders (Class Arachnida), 2 articles of each were found (Table 2).

The different attenuation mechanisms found were classified into nine categories according to what was discussed in the articles. Most of the attenuating mechanisms are repeated in multiple arthropod species. The two attenuation mechanisms with the largest number of articles found are gene duplication (14 articles), with the majority addressing duplications of acetylcholinesterase, and differential protein expression (10 articles), usually involving overexpression (Tables 3 and 4). Gene duplication was also the mechanism most commonly found in species of different arthropod orders, with eight species belonging to three Orders (including insects and arachnids species), followed by compensatory mutations in the same gene, found in seven species of three Orders (all Class Insecta). In two articles

TABLE 2: List and quantity of analyzed articles, organized according to the Order of the target organism of the study.

\begin{tabular}{lll}
\multicolumn{1}{c}{ Order } & $\begin{array}{c}\text { Number of } \\
\text { articles }\end{array}$ & \multicolumn{1}{c}{ References } \\
\hline & & $\begin{array}{l}\text { Davies et al. (1996); Chevillon et al. (1997); Guillemaud et al. (1998); Eritja and Chevillon } \\
\text { (1999); Shi et al. (2004); Le Goff et al. (2005); Berticat et al. (2008); Labbé et al. (2005; }\end{array}$ \\
Diptera & 24 & $\begin{array}{l}\text { 2007; 2014); Djogbénou et al. (2009); Jones et al. (2012); Martins et al. (2013); Remnant et } \\
\text { al. (2013); Hou et al. (2014); Linss et al. (2014); Diniz et al. (2015); Assogba et al. (2015; } \\
\text { 2016; 2018); Liebman et al. (2015); Hawkes et al. (2016); Kasai et al. (2017); Milesi et al. } \\
\text { (2017) }\end{array}$ \\
\hline Hemiptera & 07 & $\begin{array}{l}\text { Hick et al. (1996); Silva et al. (2012); Germano and Picollo (2015); Gordon et al. (2015); } \\
\text { Zhang et al. (2016); Wang et al. (2017); Yang et al. (2018) }\end{array}$ \\
\hline Coleoptera & 06 & $\begin{array}{l}\text { Arnaud and Haubruge (2002); Araújo et al. (2008a; 2008b); Lopes et al. (2010); Silva et } \\
\text { al. (2010a; 2010b) }\end{array}$ \\
\hline Lepidoptera & 05 & $\begin{array}{l}\text { Zhao et al. (2000); Dai et al. (2016); Xia et al. (2018); Gutiérrez et al. (2019); Li et al. } \\
\text { (2019) }\end{array}$ \\
\hline Ixodida & 02 & Temeyer et al. (2012; 2013) \\
\hline Trombidiformes & 02 & Kwon et al. (2010; 2012) \\
\hline Total & $\mathbf{4 6}$ & \\
\hline
\end{tabular}


(ARNAUD; HAUBRUGE, 2002; KWON et al., 2012), the authors cite two mechanisms as possible fitness attenuators (Table 3). The two classes of insecticides most cited in the articles, and possibly related to the selection of different mechanisms to mitigate the fitness cost in resistant arthropods are organophosphates and pyrethroids (Table 4).

TABLE 3: List of mitigation mechanisms and articles where they were found, with the number of articles for each Order that describes the mechanism.

\begin{tabular}{|c|c|c|}
\hline Mechanisms classification & $\begin{array}{l}\text { Order and number } \\
\quad \text { of articles }{ }^{\#}\end{array}$ & References \\
\hline Gene duplication & $\begin{array}{l}\text { Diptera: } 10 \\
\text { Trombidiformes: } 2 \\
\text { Ixodida: } 2\end{array}$ & $\begin{array}{l}\text { Labbé et al. (2007; 2014); Djogbénou et al. (2009); Kwon et } \\
\text { al. (2010; 2012a); Martins et al. (2013); Remnant et al. (2013); } \\
\text { Temeyer et al. (2012; 2013); Liebman et al. (2015); Assogba et al. } \\
\text { (2015; 2016; 2018); Milesi et al. (2017) }\end{array}$ \\
\hline Differential protein expression & $\begin{array}{l}\text { Diptera: } 1 \\
\text { Coleoptera: } 5 \\
\text { Hemiptera: } 4\end{array}$ & $\begin{array}{l}\text { Hick et al. (1996); Araújo et al. (2008a; 2008b); Hou et al. (2014); } \\
\text { Silva et al. (2012); Silva et al. (2010a; 2010b); Lopes et al. (2010); } \\
\text { Wang et al. (2017); Yang et al. (2018) }\end{array}$ \\
\hline $\begin{array}{l}\text { Compensatory mutations in the } \\
\text { same gene }\end{array}$ & $\begin{array}{l}\text { Diptera: } 5 \\
\text { Hemiptera: } 1 \\
\text { Lepidoptera: } 1\end{array}$ & $\begin{array}{l}\text { Shi et al. (2004); Le Goff et al. (2005); Jones et al. (2012); Linss } \\
\text { et al. (2014); Dai et al. (2016); Zhang et al. (2016); Kasai et al. } \\
\text { (2017) }\end{array}$ \\
\hline $\begin{array}{l}\text { Substitution in overexpression } \\
\text { of esterase loci over time }\end{array}$ & Diptera: 4 & $\begin{array}{l}\text { Chevillon et al. (1997); Guillemaud et al. (1998); Eritja and } \\
\text { Chevillon (1999); Labbé et al. (2005) }\end{array}$ \\
\hline $\begin{array}{l}\text { Change at some development } \\
\text { stage }\end{array}$ & $\begin{array}{l}\text { Diptera: } 1 \\
\text { Hemiptera: } 2 \\
\text { Lepidoptera: } 1\end{array}$ & $\begin{array}{l}\text { Diniz et al. (2015); Germano and Picollo (2015); Gordon et al. } \\
\text { (2015); Gutiérrez et al. (2019) }\end{array}$ \\
\hline Fitness modifier gene & $\begin{array}{c}\text { Diptera: } 2 \\
\text { Coleoptera: } 1\end{array}$ & $\begin{array}{l}\text { Davies et al. (1996); Arnaud and Haubruge }\left(2002^{\mathrm{b}}\right) \text {; Hawkes et al. } \\
\text { (2016) }\end{array}$ \\
\hline $\begin{array}{l}\text { Substitutive mutation in the } \\
\text { same gene }\end{array}$ & Lepidoptera: 1 & Zhao et al. (2000) \\
\hline $\begin{array}{l}\text { Differences in the microbial } \\
\text { community }\end{array}$ & Lepidoptera: 2 & Xia et al. (2018); Li et al. (2019) \\
\hline Mutation in another gene & Diptera: 1 & Berticat et al. (2008) \\
\hline Total & 46 & \\
\hline
\end{tabular}

a: Article also cites another mechanism: Compensatory mutations in the same gene; b: Article also cites another mechanism: Substitutive mutation in the same gene; \#: This column describes the number of articles found for each Order that describe the mechanism. 
TABLE 4: Mitigation mechanisms of the fitness cost, number of articles and class of insecticide tested or possibly responsible for the selection of the mechanism.

\begin{tabular}{lcl}
\multicolumn{1}{c}{ Mechanisms classification } & Number of articles & \multicolumn{1}{c}{ Class of insecticide $^{\mathrm{a}}$} \\
\hline Gene duplication & 14 & $\begin{array}{l}\text { Organophosphate (7); Pyrethroid (1); Organochlorine (1); } \\
\text { Organophosphate and Carbamate (5); }\end{array}$ \\
\hline $\begin{array}{l}\text { Differential protein expression } \\
\begin{array}{l}\text { Compensatory mutations in the same } \\
\text { gene }\end{array}\end{array}$ & 10 & $\begin{array}{l}\text { Pyrethroid (6); Organophosphate (3); Pyrethroid, } \\
\text { Organophosphate and Carbamate (1) }\end{array}$ \\
\hline $\begin{array}{l}\text { Substitution in overexpression of } \\
\text { esterase loci over time }\end{array}$ & 04 & $\begin{array}{l}\text { Pirazol (Fipronil) (2); Carbamate(1); Organophophate and } \\
\text { carbamate (1); Pyrethroid (3) }\end{array}$ \\
\hline $\begin{array}{l}\text { Change at some development stage or } \\
\text { life history traits (or both) }\end{array}$ & 04 & $\begin{array}{l}\text { Organophosphate (4) } \\
\text { Neonicotinoid+Pyrethroid (1) }\end{array}$ \\
\hline $\begin{array}{l}\text { Fitness modifier gene } \\
\text { Substitutive mutation in the same gene }\end{array}$ & 01 & Organophosphate (2); ND (1) \\
\hline $\begin{array}{l}\text { Differences in the microbial } \\
\text { community }\end{array}$ & 02 & Pyrethroid \\
\hline Mutation in another gene & 01 & Pyrethroid and Carbamate \\
\hline \multicolumn{1}{c}{ Total } & $\mathbf{4 6}$ & \\
\hline
\end{tabular}

a: the number inside the parentheses in this column indicates the number of articles that cites the class of insecticide; b: resistance to a product containing a mixture of compounds from both classes of insecticides; c: ND = Not determined (Hawkes et al., 2016): are used homozygous populations for an allele $(C y p 6 g 1)$ that provides metabolic resistance to different classes of insecticides

\section{Discussion}

Overall the studies analyzed by our work targeted species with significant importance for livestock or agriculture affecting the local economy, and public health policies, due to transmission of arboviruses. The Culicidae family, Order Diptera, is the one that has been most investigated, represented mainly by the species Aedes aegypti, Anopheles gambiae, Anopheles albimanus, Culex pipiens and Culex quinquefasciatus, which are vectors of different arboviruses (CONSOLI; OLIVEIRA, 1994), which should justify the largest number of studies focusing on these organisms. Understanding the mechanisms that provide resistance in environments where different types of insecticides are present, will lead to better strategies to control the populations of these vector species, since for many of the diseases they transmit there are no vaccines available and the only way to preventing epidemic outbreaks is controlling the size of their populations
(WEAVER; REISEN, 2010). Although they are not considered disease vector species or cause economic damage, Drosophila melanogaster and Drosophila simulans species (Diptera; Drosophilidae) have also been used as a model organism in insecticide resistance and mitigation mechanism studies. Three articles were found that used Drosophila melanogaster (SHI et al., 2004; REMNANT et al., 2013; HAWKES et al., 2016) and one with Drosophila simulans (LE GOFF et al., 2005) as an organism of study. Due to the multiplicity of consequences in biological characteristics, caused by resistance alleles, negatively affecting the ability of survival, reproduction (or both) of resistant individuals, different mitigation mechanisms were selected and will be discussed below. Some articles did not present an experiment indicating or providing the action of an attenuation mechanism; its existence was suggested in the discussion of the results. 


\section{Gene duplication}

Gene duplication allows individuals to carry an extra copy containing mutations related to insecticide resistance, and another copy without changes, attenuating some of the deleterious effects of the presence of only the mutant allele. These duplications can generate permanent heterozygosity facilitating the maintenance and dissemination of resistance mutations (OTTO; YONG, 2002; MILESI et al., 2017). All gene duplications described here involve genes encoding proteins that are the target of insecticide action. Duplication in the sodium channel protein gene, which is the target of pyrethroid and DDT action, has been reported in Brazilian samples of Aedes aegypti, with variation in the number of copies, and in a strain selected in the laboratory for resistance to deltamethrin (MARTINS et al., 2013). In Drosophila melanogaster duplication was found in the gene encoding the GABA receptor, allowing individuals with mutations in one of the copies to have intermediate levels of resistance to the organochlorine dieldrin (REMNANT et al., 2013). Duplications of acetylcholinesterase genes, target of the action of organophosphates and carbamates, have been found in resistant samples of the mite Tetranychus urticae (KWON et al., 2010; 2012), in the ticks Rhipicephalus (Boophilus) microplus and Ixodes scapularis (TEMEYER et al., 2012; 2013) and in the mosquitoes Culex pipiens (LABBÉ et al., 2007; 2014; MILESI et al., 2017), Anopheles albimanus (LIEBMAN et al., 2015) and Anopheles gambiae (DJOGBÉNOU et al., 2009; ASSOGBA et al., 2015; 2016 ; 2018). In samples of natural populations of Tetranychus urticae, variation in the number of copies of the acetylcholinesterase gene was found (KWON et al., 2010), and the same was verified for Anopheles gambiae populations, including different combinations of wild and resistant copies (ASSOGBA et al., 2016; 2018).

\section{Differential protein expression}

The vast majority of articles address the differential expression of enzyme function proteins. The advantage of the differential expression of some proteins lies in the greater efficiency of digestion processes causing a greater increase in energy reserves. Higher energy reserves can provide the necessary energy for the production of detoxification proteins without necessarily reducing the energy that is used in other physiological processes. In addition, greater efficiency in protein digestion can also provide additional energy resources as well as increase the availability of amino acids for protein synthesis (SILVA et al., 2010a). Larvae of Diptera Bactrocera dorsalis, exposed to treatment with the pyrethroid $\beta$-cypermethrin, showed greater serine protease activity, which was considered a possible mechanism to mitigate the stress caused by exposure to the insecticide and could, therefore, mitigate the fitness costs caused for resistance (HOU et al., 2014). In pyrethroid resistant strains of coleoptera Sitophilus zeamais, greater activity of some enzymes was found, such as $\alpha$-amylase (LOPES et al., 2010), trehalases, lipases (ARAÚJO et al., 2008a), cysteine proteinase (ARAÚJO et al., 2008b; SILVA et al., 2010b), cellulase (ARAÚJO et al., 2008b) and trypsin-like proteinases (SILVA et al., 2010a), either by increasing gene expression or by expressing isoforms with greater activity. In Nilaparvata lugens (Hemiptera) it was found that the resistant strain R9 had fewer effects on relative fitness than the susceptible $\mathrm{S} 9$ at a lower temperature ( $\mathrm{R} 9$ had a higher copulation rate at $18^{\circ} \mathrm{C}$ ). The authors argue that this difference found at a lower temperature between strains may be related to differences in the expression of heat shock proteins, although they have not carried out experiments to prove differential expression (YANG et al., 2018). A Laodelphax striatella strain (Hemiptera) resistant to chlorpyrifos showed better fitness at a higher temperature $\left(30^{\circ} \mathrm{C}\right)$ than at a lower temperature $\left(24^{\circ} \mathrm{C}\right)$, when compared to the fitness of the susceptible strain. It was found that the resistant strain had two HSPs 70 genes that were more expressed in relation to susceptible strain, which enhanced the thermotolerance of the former, contributing to the improvement of relative fitness (WANG et al., 2017). In highly resistant clones of Hemiptera Myzus persicae (R3), inactivation of the expression of E4 esterase genes (which act in the metabolization of some insecticides) occurs through differential methylation, avoiding the overexpression of these genes in periods of absence of pressure by the insecticides (HICK et al., 1996). In another study with the same species, susceptible and resistant strains carrying one or two resistance mechanisms were analyzed, all created in a host plant 
considered favorable (pepper) and another that was not favorable (radish). A favorable and non-favorable host refers to the skill of the aphid to overcome allelochemical defense systems presented by plants. When reared in the favorable host, resistant genotypes presented less reproductive fitness compared to susceptible genotype strains. However, when created in the non-favorable host, resistant genotypes showed the best reproductive fitness in relation to susceptible ones. Resistant genotypes did not show significant differences in reproductive fitness in different hosts, but susceptible genotypes did. The analysis of the expression of six genes, including some enzymes that act in the detoxification of xenobiotics, in all strains showed that the resistant genotypes, in general, exhibited less transcriptional plasticity using diferente host plants. The authors argue that the results suggest a greater constitutive expression of the genes analyzed in these strains, including possible paralogous, and even of other related genes. Additionally, aphids living under pressure from insecticides or on plants with chemical defenses may present similar adaptive solutions for two selective agents (SILVA et al., 2012).

\section{Compensatory mutations in the same gene}

This mechanism involves the accumulation of mutations that act synergistically to confer resistance, but also minimize fitness costs for the carrier. A mutation that causes resistance can have a cost by decreasing the catalytic efficiency of the enzyme. Over time, different mutations can accumulate in the same locus so that catalytic efficiency can be restored, or the compensation can come from an increase in the affinity of binding to the substrate. One or more compensatory mutations have been described in the GABA receptor gene of Drosophila simulans (LE GOFF et al., 2005) and Nilaparvata lugens (ZHANG et al., 2016), in the acetylcholinesterase gene from Chilo suppressalis (DAI et al., 2016), Drosophila melanogaster (SHI et al., 2004) and Tetranychus urticae (KWON et al., 2012), and in the gene of the sodium channel (Kdr mutations) from Musca domestica (KASAI et al., 2017), Aedes aegypti (LINSS et al., 2014) and Anopheles gambiae (JONES et al., 2012).

\section{Substitution in overexpression of esterase loci over time}

The articles describe overproduction of protein esterases in Culex pipiens populations, which confer resistance to organophosphates and carbamates. Changes in the regulatory mechanism and co-amplification of duplicated genes are related to the overproduction of these esterases (GUILLEMAUD et al., 1998). In natural populations of Culex pipiens in Europe, changes in the frequency of the alleles from two loci, related to overproduction of esterases, have been observed over time, alternating between variants that have a higher cost in fitness and others having a lower cost. This alternation of alleles was related to the heterogeneity of environments and intensity of insecticide treatments (CHEVILLON et al., 1997; GUILLEMAUD et al., 1998; ERITJA; CHEVILLON, 1999; LABBÉ et al., 2005).

\section{Change at some development stage or life history traits (or both)}

In a population of Tecia solanivora (Lepidoptera), which presented multiple resistance to insecticides of different classes, a shorter time of larval development was verified, which could be an adaptation to reduce the time of contact with tubers and soil (or both) contaminated with insecticides, which are usually the substrates treated to wrestle it. In addition, a delay in the peak of oviposition was also found in this population, which has been suggested as a possible adaptation to compensate for the nutrients needed to complete the egg's development (GUTIÉRREZ et al., 2019). In Aedes aegypti, resistant to temephos, an extension in the time of larval development was found, which was interpreted as a compensation mechanism for the loss of energy reserves - caused by resistance -, reducing deficits related to female survival and reproduction (DINIZ et al., 2015). In the vector of Chagas disease, Triatoma infestans, longer duration and variability in the last nymph stage was found in the resistant samples, which could reflect an advantage since nymphs molting later can remain in refuges, avoiding exposure to insecticides (GERMANO; PICOLLO, 2015). In populations of the bedbug Cimex lectularius, with a history of exposure to insecticides, 
the generation time was significantly reduced, in relation to populations without this history. However, why this change was considered a benefit was not discussed exactly (GORDON et al., 2015).

\section{Fitness modifier gene}

In two articles, one with Drosophila melanogaster (HAWKES et al., 2016) and another with the beetle Tribolium castaneum (ARNAUD; HAUBRUGE, 2002), the authors do not mention which fitness modifier gene it would be, only suggesting the existence of one that would improve the fitness of resistant individuals. However, in the article with Lucilia cuprina (DAVIES et al., 1996) the authors cite the Scalloped wings (Scl) gene, homologous to the Drosophila melanogaster Notch gene, as the fitness attenuator of diazinon-resistant strains. This resistance was associated with changes in the locus Rop1, which codes for carboxylesterase E3. The existence of an interaction between the products of Rop- 1 and $S c l$ has been proposed, probably involving signaling pathways related to cell adhesion, so that developmental stability and the asymmetries observed in the resistant ones are restored.

\section{Substitutive mutation in the same gene}

The occurrence of a new allele that also provides resistance to insecticides can bring less cost to its carrier, possibly causing fewer changes in the properties of the protein, and over time replacing the variant that had the highest cost. This mechanism was verified in the sodium channel (Kdr mutations) of Heliothis virescens resistant to pyrethroids (ZHAO et al., 2000) and cited as a possible fitness costs attenuator of malation-resistant Tribolium castaneum (ARNAUD; HAUBRUGE, 2002).

\section{Differences in the microbial community}

The MR strain of Plutella xylostella, resistant to metaflumizone, showed significantly greater bacterial richness and diversity in the intestine, compared to the susceptible SS strain, and the authors suggest that a greater diversity of microorganisms may bring benefits to the host's metabolism, although they do not detail how this would happen (LI et al., 2019). In the article by Xia et al. (2018), also with Plutella xylostella, the authors argue that symbionts of the intestine are known to contribute to the development of the insect immune system; thus, these symbionts would contribute to prevent or restore possible damage to the immune system of the host caused by insecticides.

\section{Mutation in another gene}

Four strains of Culex quinquefasciatus were analyzed, one susceptible and three resistant: one resistant strain presented a mutation only in acetylcholinesterase, another only in the sodium channel gene, and another with a mutation in both genes. The BCSR strain, which had mutations in both acetylcholinesterase and sodium channel genes (insensitive to carbamates and pyrethroids), showed better fitness than the strain that only had mutations in acetylcholinesterase (insensitive to carbamates). Sodium channel and acethylcolinesterase are proteins that act in the transmission of the nervous impulse. The authors argue that the relatively higher costs caused by the malfunction of acetylcholinesterase, due to the presence of a resistance mutation, causing a reduced degradation of acetylcholine in the postsynaptic terminal region, can be partially offset by a slower release of acetylcholine due to the presence of the mutation in the sodium channel (BERTICAT et al., 2008).

Negative pleiotropic effects caused by resistance may not be easy to identify. However, testable hypotheses may arise when the molecular basis of the changes is discovered (COUSTAU et al., 2000). The phenotype of an organism is shaped by several selective pressures present in the environment in which it lives and, therefore, large phenotypic changes are expected to be harmful when the environment returns to what it was before the presence of the insecticide. Producing an enzyme that acts in the detoxification of the insecticide, for example, expends a lot of energy: a reallocation of energy used in other metabolic and development processes occurs, so an individual that produces it in excess in the absence of the insecticide would have a higher disadvantage in terms of energy (KLIOT; GHANIM, 2012; FFRENCH-CONSTANT; BASS, 2017). There are many characteristics of an organism's life history that can be analyzed to verify the existence 
of fitness costs in a population, and these analyses were carried out using both samples from natural populations and laboratory strains. However, there are certain aspects of fitness that can only be analyzed outside of laboratory conditions; for example, studies of survival overwintering, as well as the influence of the presence of entomopathogens, natural enemies, and the availability of different host plants with their chemical defense mechanisms (KLIOT; GHANIM, 2012).

Changes caused by resistance can also influence rates of infection, development and transmission of pathogens. A resistance mechanism can have opposite effects on each of these components, that is, it can increase the life span of the vector and interfere with the development of the parasite (RIVERO et al., 2010). In the absence of a fitness cost, resistance will remain, and the only alternative will be the introduction of a new chemical class to which no pre-existing mechanism can confer cross resistance (FFRENCH-CONSTANT; BASS, 2017).

\section{Acknowledgments}

The authors are grateful to Dr. Bibiana Sgorla de Almeida (Multi-User Laboratory for Biological Studies, Universidade Federal de Santa Catarina, Brazil) for the suggestions that contributed to data analysis and article writing.

\section{References}

ARAÚJO, R. A.; GUEDES, R. N. C.; OLIVEIRA, M. G. A.; FERREIRA, G. H. Enhanced activity of carbohydrate- and lipidmetabolizing enzymes in insecticide-resistant populations of the maize weevil, Sitophilus zeamais. Bulletin of Entomological Research, Cambridge, v. 98, n. 4, p. 417-424, 2008a.

ARAÚJO, R. A.; GUEDES, R. N. C.; OLIVEIRA, M. G. A.; FERREIRA, G. H. Enhanced proteolytic and cellulolytic activity in insecticide-resistant strains of the maize weevil, Sitophilus zeamais. Journal of Stored Products Research, Elmsford, v. 44, n. 4, p. 354-359, 2008b.

ARNAUD, L.; HAUBRUGE, E. Insecticide resistance enhances male reproductive success in a beetle. Evolution, New York, v. 56, n. 12 , p. $2435-2444,2002$

ARTHROPOD PESTICIDE RESISTANCE DATABASE. 2020. Available in: $<$ http://www.pesticideresistance.org/>.
ASSOGBA, B. S.; ALOUT, H.; KOFFI, A.; PENETIER, C.; DJOGBÉNOU, L. S.; MAKOUNDOU, P.; WEILL, M.; LABBÉ, P. Adaptive deletion in resistance gene duplications in the malaria vector Anopheles gambiae. Evolutionary Applications, Malden, v. 11, n. 8 , p. 1245-1256, 2018.

ASSOGBA, B. S.; DJOGBÉNOU, L. S.; MILESI, P.; BERTHOMIEU, A.; PEREZ, J.; AYALA, D.; CHANDRE, F.; MAKOUTODÉ, M.; LABBÉ, P.; WEILL, M. An ace-1 gene duplication resorbs the fitness cost associated with resistance in Anopheles gambiae, the main malaria mosquito. Scientific Reports, London, v. 5, p. 19-21, 2015.

ASSOGBA, B. S.; MILESI, P.; DJOGBÉNOU, L. S.; BERTHOMIEU, A.; MAKOUNDOU, P.; BABA-MOUSSA, L. S.; FISTON-LAVIER, A. S.; BELKHIR, K.; LABBÉ, P.; WEILL, M. The ace-1 locus is amplified in all resistant Anopheles gambiae mosquitoes: fitness consequences of homogeneous and heterogeneous duplications. Plos Biology, San Francisco, v. 14, n. 12, p. 1-26, 2016.

BAJDA, S.; RIGA, M.; WYBOUW, N.; PAPADAKI, S.; OURANOU, E.; FOTOUKKIAII, S. M.; VONTAS, J.; LEEUWEN, T. van. Fitness costs of key point mutations that underlie acaricide target-site resistance in the two-spotted spider mite Tetranychus urticae. Evolutionary Applications, Malden, v. 11, n. 9, p. 15401553,2018

BERTICAT, C.; BONNET, J.; DUCHON, S.; AGNEW, P.; WEILL, M.; CORBEL, V. Costs and benefits of multiple resistance to insecticides for Culex quinquefasciatus mosquitoes. BMC Evolutionary Biology, London, v. 8, n. 1, p. 1-9, 2008.

BOIVIN, T.; CHABERT D'HIÈRES, C.; BOUVIER, J. C.; BESLAY, D.; SAUPHANOR, B. Pleiotropy of insecticide resistance in the codling moth, Cydia pomonella. Entomologia Experimentalis et Applicata, Dordrecht, v. 99, p. 381-386, 2001.

BRAGA, I. A.; VALLE, D. Aedes aegypti: inseticidas, mecanismos de ação e resistência. Epidemiologia e Serviços de Saúde, Brasília, v. 16, n. 4, p. 279-293, 2007.

BRITO, L. G.; BARBIERI, F. S.; ROCHA, R. B.; SANTOS, A. P. L.; SILVA, R. R.; RIBEIRO, E. S.; GUERRERO, F.; FOIL, L.; OLIVEIRA, M. C. S. Pyrethroid and organophosphate pesticide resistance in field populations of horn fly in Brazil. Medical and Veterinary Entomology, Oxford, v. 33, n. 1, p. 121-130, 2019.

BRITO, L. P.; LINSS, J. G. B.; LIMA-CAMARA, T. N.; BELINATO, T. A.; PEIXOTO, A. A.; LIMA, J. B. P.; VALLE, D.; MARTINS, A. J. Assessing the effects of Aedes aegypti kdr mutations on pyrethroid resistance and its fitness cost. Plos One, San Francisco, v. 8, n. 4, p. 1-10, 2013.

CHEVILlON, C.; BOURGUET, D.; ROUSSET, F.; PASTEUR, N.; RAYMOND, M. Pleiotropy of adaptive changes in populations: comparisons among insecticide resistance genes in Culex pipiens. Genetical Research, London, v. 70, n. 3, p. 195-203, 1997.

CONSOLI, R. A. G. B.; OLIVEIRA, R. L. Classificação e principais espécies de importância sanitária. In: CONSOLI, R. A. G. B.; OLIVEIRA, R. L. (Ed.). Principais mosquitos de importância sanitária no Brasil. 20. ed. Rio de Janeiro, Editora Fiocruz, 1994. p. 57-154.

COUSTAU, C.; CHEVILLON, C.; FFRENCH-CONSTANT, R. Resistance to xenobiotics and parasites: can we count the cost? 
Trends in Ecology and Evolution, Cambridge, v. 15 n. 9, p. 378383, 2000.

DAI, S. M.; CHANG, C.; HUANG, X. Y. Distinct contributions of A314S and novel R667Q substitutions of acetylcholinesterase 1 to carbofuran resistance of Chilo suppressalis Walker. Pest Management Science, Malden, v. 72, n. 7, p. 1421-1426, 2016.

DAVID, M. R.; GARCIA, G. A.; VALLE, D.; MACIEL-DEFREITAS, R. Insecticide resistance and fitness: the case of four Aedes aegypti populations from different Brazilian regions. BioMed Research International, Cairo, v. 2018, n. 9, p. 1-12, 2018.

DAVIES, A. G.; GAME, A. Y.; CHEN, Z.; WILLIAMS, T. J.; GOODALL, S.; YEN, J. L.; MCKENZIE, J. A.; BATTERHAM, P. Scalloped wings is the Lucilia cuprina Notch homologue and a candidate for the modifier of fitness and asymmetry of diazinon resistance. Genetics, Austin, v. 143, n. 3, p. 1321-1337, 1996.

DINIZ, D. F. A.; MELO-SANTOS, M. A. V.; SANTOS, E. M. D. M.; BESERRA, E. B.; HELVECIO, E.; CARVALHO-LEANDRO, D.; SANTOS, B. S. dos; MENEZES LIMA, V. L. de; AYRES, C. F. J. Fitness cost in field and laboratory Aedes aegypti populations associated with resistance to the insecticide temephos. Parasites \& Vectors, London, v. 8, article 662, 2015.

DJOGBÉNOU, L.; LABBÉ, P.; CHANDRE, F.; PASTEUR, N.; WEILL, M. Ace-1 duplication in Anopheles gambiae: a challenge for malaria control. Malaria Journal, Liverpool, v. 8, n. 1, p. 1-6, 2009.

DURON, O.; LABBÉ, P.; BERTICAT, C.; ROUSSET, F.; GUILlOT, S.; RAYMOND, M.; WEILL, M. High Wolbachia density correlates with cost of infection for insecticide resistant Culex pipiens mosquitoes. Evolution, New York, v. 60, n. 2, p. 303-314, 2006.

ERITJA, R.; CHEVILLON, C. Interruption of chemical mosquito control and evolution of insecticide resistance genes in Culex pipiens (Diptera: Culicidae). Journal of Medical Entomology, Lanham, v. 36, n. 1, p. 41-49, 1999.

FFRENCH-CONSTANT, R. H.; BASS, C. Does resistance really carry a fitness cost? Current Opinion in Insect Science, Amsterdam, v. 21, p. 39-46, 2017.

GERMANO, M. D.; PICOLlO, M. I. Reproductive and developmental costs of deltamethrin resistance in the Chagas disease vector Triatoma infestans. Journal of Vector Ecology, Santa Ana, v. 40, n. 1, p. 59-65, 2015.

GORDON, J. R.; POTTER, M. F.; HAYNES, K. F. Insecticide resistance in the bed bug comes with a cost. Scientific Reports, London, v. 5, article 10807, 2015.

GUILLEMAUD, T.; LENORMAND, T.; BOURGUET, D.; CHEVILLON, C.; PASTEUR, N.; RAYMOND, M. Evolution of resistance in Culex pipiens: allele replacement and changing environment. Evolution, New York, v. 52, n. 2, p. 443-453, 1998.

GUTIÉRREZ, Y.; BACCA, T.; ZAMBRANO, L. S.; PINEDA, M.; GUEDES, R. N. C. Trade-off and adaptive cost in a multipleresistant strain of the invasive potato tuber moth Tecia solanivora. Pest Management Science, Malden, v. 75, n. 6, p. 1655-1662, 2019.

HAWKES, M. F.; GAMBLE, C. E.; TURNER, E. C. R.; CAREY, M. R.; WEDELL, N.; HOSKEN, D. J. Intralocus sexual conflict and insecticide resistance. Proceedings of the Royal Society B: Biological Sciences, London, v. 283, n. 1843, p. 1-9, 2016.

HEMINGWAY, J. The molecular basis of two contrasting metabolic mechanisms of insecticide resistance. Insect Biochemistry and Molecular Biology, Oxford, v. 30, n. 11, p. 1009-1015, 2000.

HEMINGWAY, J.; HAWKES, N. J.; MCCARROLL, L.; RANSON, $\mathrm{H}$. The molecular basis of insecticide resistance in mosquitoes. Insect Biochemistry and Molecular Biology, Oxford, v. 34, n. 7, p. 653-665, 2004.

HEMINGWAY, J.; RANSON, H. Insecticide resistance in insect vectors of human disease. Annual Review of Entomology, Palo Alto, v. 45, n. 1, p. 371-391, 2000

HICK, C. A.; FIELD, L. M.; DEVONSHIRE, A. L. Changes in the methylation of amplified esterase DNA during loss and reselection of insecticide resistance in peach-potato aphids, Myzus persicae. Insect Biochemistry and Molecular Biology, Oxford, v. 26, n. 1, p. 41-47, 1996.

HOU, M. Z.; SHEN, G. M.; WEI, D.; LI, Y. L.; DOU, W.; WANG, J. J. Characterization of bactrocera dorsalis serine proteases and evidence for their indirect role in insecticide tolerance. International Journal of Molecular Sciences, Basel, v. 15, n. 2, p. 3272-3286, 2014.

HSU, J. C.; LIN, Y. Y.; CHANG, C. C.; HUA, K. H.; CHEN, M. J. M.; HUANG, L. H.; CHIEN-YU. Discovery of organophosphate resistance-related genes associated with well-known resistance mechanisms of Plutella xylostella (L.) (Lepidoptera: Plutellidae) by RNA-Seq. Journal of Economic Entomology, Riverside, v. 109, n. 3, p. 1378-1386, 2016.

IRAC - THE INSECTICIDE RESISTANCE ACTION COMMITTEE. Mode of action classification. 4. ed. 2014. Available in: <https://docs.wixstatic.com/ugd/2bed6c_e2ccae06895a43498 eca3addc7970ca1.pdf $>$.

JONES, C. M.; LIYANAPATHIRANA, M.; AGOSSA, F. R.; WEETMAN, D.; RANSON, H.; DONNELLY, M. J.; WILDING, C. S. Footprints of positive selection associated with a mutation (N1575Y) in the voltage-gated sodium channel of Anopheles gambiae. Proceedings of the National Academy of Sciences of the United States of America, Washington, v. 109, n. 17, 6614$6619,2012$.

KASAI, S.; SUN, H.; SCOTT, J. G. Diversity of knockdown resistance alleles in a single house fly population facilitates adaptation to pyrethroid insecticides. Insect Molecular Biology, Oxford, v. 26, n. 1, p. 13-24, 2017.

KLIOT, A.; GHANIM, M. Fitness costs associated with insecticide resistance. Pest Management Science, Malden, v. 68, n. 11, p. 1431-1437, 2012.

KWON, D. H.; CHOI, J. Y.; JE, Y. H.; LEE, S. H. The overexpression of acetylcholinesterase compensates for the reduced catalytic activity caused by resistance-conferring mutations in Tetranychus urticae. Insect Biochemistry and Molecular Biology, Oxford, v. 42, n. 3, 212-219, 2012.

KWON, D. H.; CLARKT, J. M.; LEE, S. H. Extensive gene duplication of acetylcholinesterase associated with organophosphate resistance in the two-spotted spider mite. Insect Molecular Biology, Oxford, v. 19, n. 2, p. 195-204, 2010. 
LABBÉ, P.; BERTHOMIEU, A.; BERTICAT, C.; ALOUT, H.; RAYMOND, M.; LENORMAND, T.; WEILL, M. Independent duplications of the acetylcholinesterase gene conferring insecticide resistance in the mosquito Culex pipiens. Molecular Biology and Evolution, Oxford, v. 24, n. 4, p. 1056-1067, 2007.

LABBÉ, P.; LENORMAND, T.; RAYMOND, M. On the worldwide spread of an insecticide resistance gene: a role for local selection. Journal of Evolutionary Biology, Basel, v. 18, n. 6, p. 1471-1484, 2005.

LABBÉ, P.; MILESI, P.; YÉBAKIMA, A.; PASTEUR, N.; WEILL, M.; LENORMAND, T. Gene-dosage effects on fitness in recent adaptive duplications: ACE-1 in the mosquito Culex pipiens. Evolution, New York, v. 68, n. 7, p. 2092-2101, 2014.

LE GOFF, G.; HAMON, A.; BERGE, J. B.; AMICHOT, M. Resistance to fipronil in Drosophila simulans: influence of two point mutations in the RDL GABA receptor subunit. Journal of Neurochemistry, Malden, v. 92, n. 6, p. 1295-1305, 2005.

LI, D.; ZHANG, Y.; LI, W.; TANG, T.; WAN, H.; YOU, H.; LI, J. Fitness and evolution of insecticide resistance associated with gut symbionts in metaflumizone-resistant Plutella xylostella. Crop Protection, Guildford, v. 124, article 104869, 2019.

LIEBMAN, K. A.; BILLETER, S. A.; YOSHIMIZU, M. H.; YANG, F.; METZGER, M. E.; SCHILDHAUER, S.; PAYNE, R.; PAKINGAN, M. J.; HU, R.; KRAMER, V.; PADGETT, K. A. Identification of molecular determinants of resistance to pyrethroid insecticides in Aedes aegypti (Diptera: Culicidae) populations in California, USA. Journal of Medical Entomology, Lanham, v. 56, n. 5, p. 1353-1358, 2019.

LIEBMAN, K. A.; PINTO, J.; VALlE, J.; PALOMINO, M.; VIZCAINO, L.; BROGDON, W.; LENHART, A. Novel mutations on the ace-1 gene of the malaria vector Anopheles albimanus provide evidence for balancing selection in an area of high insecticide resistance in Peru. Malaria Journal, Liverpool, v. 14, article $74,2015$.

LINSS, J. G. B.; BRITO, L. P.; GARCIA, G. A.; ARAKI, A. S.; BRUNO, R. V.; LIMA, J. B. P.; VALLE, D.; MARTINS, A. J. Distribution and dissemination of the Val1016Ile and Phe1534Cys $K d r$ mutations in Aedes aegypti Brazilian natural populations. Parasites \& Vectors, London, v. 7, article 25, 2014.

LOPES, K. V. G.; SILVA, L. B.; REIS, A. P.; OLIVEIRA, M. G. A.; GUEDES, R. N. C. Modified $\alpha$-amylase activity among insecticideresistant and -susceptible strains of the maize weevil, Sitophilus zeamais. Journal of Insect Physiology, Oxford, v. 56, n. 9, p. 1050-1057, 2010.

MA, K.; TANG, Q.; XIA, J.; LV, N.; GAO, X. Fitness costs of sulfoxaflor resistance in the cotton aphid, Aphis gossypii, Glover. Pesticide Biochemistry and Physiology, San Diego, v. 158, p. 4046, 2019

MARTINS, A. J.; BRITO, L. P.; LINSS, J. G. B.; RIVAS, G. B. S.; MACHADO, R.; BRUNO, R.V.; LIMA, J. B. P.; VALLE, D.; PEIXOTO, A. A. Evidence for gene duplication in the voltage gated sodium channel gene of Aedes aegypti. Evolution, Medicine, and Public Health, New York, v. 2013, n. 1, p. 148-160, 2013.

MATHENGE, E. M.; GIMNIG, J. E.; KOLCZAK, M.; OMBOK, M.; IRUNGU, L. W.; HAWLEY, W. A. Effect of permethrinimpregnated nets on exiting behavior, blood feeding success, and time of feeding of malaria mosquitoes (Diptera: Culicidae) in western Kenya. Journal of Medical Entomology, Lanham, v. 38, n. 4, p. 531-536, 2001

MILESI, P.; WEILL, M.; LENORMAND, T.; LABBÉ, P. Heterogeneous gene duplications can be adaptive because they permanently associate overdominant alleles. Evolution Letters, London, v. 1, n. 3, p. 169-180, 2017.

OTTO, S. P.; YONG P. The evolution of gene duplicates. Advances in Genetics, New York, v. 46, p. 451-483, 2002.

REMNANT, E. J.; GOOD, R. T.; SCHIMIDT, J. M.; LUMB, C.; ROBIN, C.; DABORN, P. B. Gene duplication in the major insecticide target site, Rdl, in Drosophila melanogaster. Proceedings of the Royal Society B: Biological Sciences, London, v. 110, n. 36, p. 14705-14710, 2013.

RIBEIRO, L. M. S.; WANDERLEY-TEIXEIRA, V.; FERREIRA, H. N.; TEIXEIRA, Á. A. C.; SIQUEIRA, H. A. A. Fitness costs associated with field-evolved resistance to chlorantraniliprole in Plutella xylostella (Lepidoptera: Plutellidae). Bulletin of Entomological Research, Cambridge, v. 104, n. 1, p. 88-96, 2014. RIVERO, A.; MAGAUD, A.; NICOT, A.; VÉZILIER, J. Energetic cost of insecticide resistance in Culex pipiens mosquitoes. Journal of Medical Entomology, Lanham, v. 48, n. 3, p. 694-700, 2011.

RIVERO, A.; VÉZILLIER, J.; WEILL, M.; READ, A. F.; GANDON, S. Insecticide control of vector-borne diseases: when is insecticide resistance a problem? Plos Pathogens, San Francisco, v. 6, n. 8, e1001000, 2010.

SHI, M. A.; LOUGARRE, A.; ALIES, C.; FRÉMAUX, I.; TANG, Z. H.; STOJAN, J.; FOURNIER, D. Acetylcholinesterase alterations reveal the fitness cost of mutations conferring insecticide resistance. BMC Evolutionary Biology, London, v. 4, p. 1-8, 2004.

SILVA, A. X.; BACIGALUPE, L. D.; LUNA-RUDLOFF, M.; FIGUEROA, C. C. Insecticide resistance mechanisms in the green peach aphid Myzus persicae (Hemiptera: Aphididae) II: costs and benefits. Plos One, San Francisco, v. 7, n. 6, p. 29-36, 2012.

SILVA, L. B.; REIS, A. P.; PEREIRA, E. J. G.; OLIVEIRA, M. G. A.; GUEDES, R. N. C. Partial purification and characterization of trypsin-like proteinases from insecticide-resistant and -susceptible strains of the maize weevil, Sitophilus zeamais. Comparative Biochemistry and Physiology Part B: Biochemistry and Molecular Biology, New York, v. 155, n. 1, p. 12-19, 2010a.

SILVA, L. B.; REIS, A. P.; PEREIRA, E. J. G.; OLIVEIRA, M. G. A.; GUEDES, R. N. C. Altered cysteine proteinase activity in insecticide-resistant strains of the maize weevil: Purification and characterization. Comparative Biochemistry and Physiology Part B: Biochemistry and Molecular Biology, New York, v. 157, n. 1, p. $80-87,2010$ b.

SOMERS, J.; LUONG, H. N. B.; BATTERHAM, P.; PERRY, T. Deletion of the nicotinic acetylcholine receptor subunit gene $\mathrm{D} \alpha 1$ confers insecticide resistance, but at what cost? Fly, Austin, v. 12, n. 1, p. 46-54, 2018.

TEMEYER, K. B.; OLAFSON, P. U.; PRUETT, J. H. Sequence polymorphism in acetylcholinesterase transcripts and genotyping survey of BmAChE1 in laboratory and Mexican strains of Rhipicephalus (Boophilus) microplus. Journal of Medical Entomology, Lanham, v. 49, n. 3, p. 555-562, 2012. 
TEMEYER, K. B.; TUCKOW, A. P.; BRAKE, D. K.; LI, A. Y.; PÉREZ DE LEÓN, A. A. Acetylcholinesterases of blood-feeding flies and ticks. Chemico-Biological Interactions, Clare, v. 203, n. 1, p. 319-322, 2013.

WANG, L.; SHAN, D.; ZHANG, Y.; LIU, X.; SUN, Y.; ZHANG, Z.; FANG, J. Effects of high temperature on life history traits and heat shock protein expression in chlorpyrifos-resistant Laodelphax striatella. Pesticide Biochemistry and Physiology, San Diego, v. 136, p. 64-69, 2017.

WEAVER, S. C.; REISEN, W. K. Present and future arboviral threats. Antiviral Research, Leuven, v. 85, n. 2, p. 328-345, 2010.

WEETMAN, D.; MITCHELL, S. N.; WILDING, C. S.; BIRKS, D. P.; YAWSON, A. E.; ESSANDOH, J.; MAWEJJE, H. D.; DJOGBENOU, L. S.; STEEN, K.; RIPPON, E. J.; CLARKSON, C. S.; FIELD, S. G.; RIGDEN, D. J.; DONNELLY, M. J. Contemporary evolution of resistance at the major insecticide target site gene Ace1 by mutation and copy number variation in the malaria mosquito Anopheles gambiae. Molecular Ecology, Vancouver, v. 24, n. 11, p. 2656-2672, 2015.

VERNON, S. W.; GOODCHILD, J.; BAINES, R. A. The VAChT $Y 49 \mathrm{~N}$ mutation provides insecticide-resistance but perturbs evoked cholinergic neurotransmission in Drosophila. Plos One, San Francisco, v. 13, n. 9, p. 1-23, 2018.

XIA, X.; SUN, B.; GURR, G. M.; VASSEUR, L.; XUE, M.; YOU, M. Gut microbiota mediate insecticide resistance in the diamondback moth, Plutella xylostella (L.). Frontiers in Microbiology, Lausanne, v. 9, article 25, 2018.
YANG, B. J.; LIU, M. L.; ZHANG, Y. X.; LIU, Z. W. Effects of temperature on fitness costs in chlorpyrifos-resistant brown planthopper, Nilaparvata lugens (Hemiptera: Delphacidae). Insect Science, Malden, v. 25, n. 3, p. 409-417, 2018.

YING, X.; CHI, Q.; GE, M.; LIU, Y.; CHEN, L.; LI, F.; CHENG, L. Analysis of UB and L40, related to deltamethrin stress in the diamondback moth, Plutella xylostella (L.). Gene, Amsterdam, v. 684, p. 149-153, 2019.

ZHANG, L. J.; WU, Z. L.; WANG, K. F.; LIU, Q.; ZHUANG, H. M.; WU, G. Trade-off between thermal tolerance and insecticide resistance in Plutella xylostella. Ecology and Evolution, Sheffield, v. 5, n. 2, p. 515-530, 2015.

ZHANG, Y.; MENG, X.; YANG, Y.; LI, H.; WANG, X.; YANG, B.; ZHANG, J.; LI, C.; MILLAR, N. S.; LIU, Z. Synergistic and compensatory effects of two point mutations conferring target-site resistance to fipronil in the insect GABA receptor RDL. Scientific Reports, London, v. 6, n. 1, p. 1-11, 2016.

ZHAO, Y.; PARK, Y.; ADAMS, M. E. Functional and evolutionary consequences of pyrethroid resistance mutations in S6 transmembrane segments of a voltage-gated sodium channel. Biochemical and Biophysical Research Communications, Orlando, v. 278, n. 3, p. 516-521, 2000. 